\title{
Anti-Oxidative, Metal Chelating and Radical Scavenging Effects of Protein Hydrolysates from Blue-spotted Stingray
}

\author{
Tsun-Thai Chai ${ }^{1,2 *}$, Shi-Ruo Tong ${ }^{2}$, Yew-Chye Law ${ }^{2}$, Nor Ismaliza Mohd \\ Ismail $^{1,3}$, Fazilah Abd Manan ${ }^{4}$ and Fai-Chu Wong ${ }^{1,2}$ \\ ${ }^{1}$ Centre for Biodiversity Research, ${ }^{2}$ Department of Chemical Science, ${ }^{3}$ Department of Biological Science, Faculty of Science, \\ Universiti Tunku Abdul Rahman, 31900 Kampar, ${ }^{4}$ Department of Biosciences and Health Sciences, Faculty of Biosciences and \\ Medical Engineering, Universiti Teknologi Malaysia, 81310 UTM Johor Bahru, Malaysia
}

*For correspondence: Email: chaitt@utar.edu.my; Tel: +605-468 8888 Ext: 4516

Received: 19 April 2015

Revised accepted: 2 July 2015

\begin{abstract}
Purpose: To evaluate protein hydrolysates and membrane ultrafiltration fractions of blue-spotted stingray for metal chelating and radical scavenging activities, as well as protection against oxidative protein damage.

Methods: Stingray protein isolates were hydrolysed with alcalase, papain and trypsin for $3 \mathrm{~h}$. Alcalase hydrolysate was fractionated by membrane ultrafiltration to yield $<3,3-10$ and $>10 \mathrm{kDa}$ fractions. Peptide contents, iron and copper chelating activity, 2, 2'-azino-bis(3-ethylbenzothiazoline-6-sulphonic acid) (ABTS) and hydroxyl radical scavenging activities, and protection against oxidative protein damage were evaluated.

Results: Three-hour alcalase hydrolysate $(3 A H)$ had the highest peptide content and the lowest half maximal effective concentration (EC $\left.C_{50}\right)$ for ABTS radical scavenging $(793.9 \mu \mathrm{g} / \mathrm{mL})$, hydroxyl radical scavenging $(6.93 \mathrm{mg} / \mathrm{mL})$, iron chelating $(116.4 \mu \mathrm{g} / \mathrm{mL})$ and copper chelating activity $(2136.9 \mu \mathrm{g} / \mathrm{mL})$ among the hydrolysates. Among the fractions of $3 A H,<3 \mathrm{kDa}$ fraction had the best iron chelating activity, 3 - $10 \mathrm{kDa}$ fraction exhibited the highest ABTS radical scavenging activity, while $>10 \mathrm{kDa}$ fraction showed the best copper chelating activity. The $<3 \mathrm{kDa}$ and $3-10 \mathrm{kDa}$ fractions had similar levels of hydroxyl radical scavenging activity to reduced glutathione. The protective effects of $3 \mathrm{AH}$ and $<$ $3 \mathrm{kDa}$ fraction against oxidative protein damage were comparable to that of reduced glutathione.

Conclusion: Alcalase is the best protease for producing hydrolysates with metal chelating and antioxidant activities from stingray proteins. Alcalase hydrolysate, specifically its $<3 \mathrm{kDa}$ fraction, has potential for future applications in antioxidant therapy and health food formulation.
\end{abstract}

Keywords: Dasyatis kuhlii, Membrane ultrafiltration, Protein hydrolysate, Glutathione, Peptide content, Metal chelating, Radical scavenging

Tropical Journal of Pharmaceutical Research is indexed by Science Citation Index (SciSearch), Scopus, International Pharmaceutical Abstract, Chemical Abstracts, Embase, Index Copernicus, EBSCO, African Index Medicus, JournalSeek, Journal Citation Reports/Science Edition, Directory of Open Access Journals (DOAJ), African Journal Online, Bioline International, Open-J-Gate and Pharmacy Abstracts

\section{INTRODUCTION}

In recent years, the antioxidant potential of protein hydrolysates derived from edible fishes and other animal sources has generated great interests among researchers [1-3]. Proteases of plant, animal and microbial origins, such as papain, trypsin, chymotrypsin, neutrase, and alcalase, have been used in the production of antioxidative fish protein hydrolysates (FPH) $[2,3]$. The antioxidant capacity of FPH has been demonstrated through free radical scavenging, metal chelating, lipid peroxidation inhibition and other antioxidant assays [3]. The potential applications of $\mathrm{FPH}$, including their use as 
antioxidants to extend the shelf-life of meat products as well as their health-promoting and disease-preventive effects, have been discussed in recent reviews [2,3]. To date, most studies have focused on edible, bony marine fishes, such as salmon and tuna. Very little attention was given to the antioxidant potential of protein hydrolysates prepared from edible, cartilaginous marine fishes, such as stingrays.

The objective of this study was to assess the antioxidant capacity of protein hydrolysates which were produced from the blue-spotted stingray by enzymatic hydrolysis using alcalase, papain and trypsin. Blue-spotted stingray was chosen because the antioxidant capacity of the protein hydrolysates of this edible, commercial fish species has never been previously investigated. The three hydrolysates and peptidic fractions derived from alcalase hydrolysate via membrane ultrafiltration were tested for their metal chelating and free radical scavenging activities, as well as their ability to protect against oxidative protein damage.

\section{EXPERIMENTAL}

\section{Protein isolation from fish sample}

Blue-spotted stingray (Dasyatis kuhlii, Family Dasyatidae) was purchased from a local market in Kampar, Malaysia, in May 2014. The species of the fish was identified by Mr Yusri Yusuf, a fish taxonomist of the Institute of Oceanography and Environment, Universiti Malaysia Terengganu. The fish sample was eviscerated and cut into small chunks. Protein isolates were prepared from the fish sample by using the alkaline $\mathrm{pH}$ shift method as previously described [4], with slight modifications. The protein pellet collected was used for hydrolysate preparation as described below. Protein content of the protein isolate was determined using Bradford's method [5].

\section{Preparation of fish protein hydrolysates}

Protein hydrolysates were prepared from the stingray protein isolate by enzymatic hydrolysis using three selected proteases: alcalase, papain and trypsin. The protein isolates were separately dissolved in $100 \mathrm{mM}$ sodium phosphate buffer, adjusted to $\mathrm{pH} 8.5$ for alcalase hydrolysis; to $\mathrm{pH}$ 7.0 for papain hydrolysis, and to $\mathrm{pH} 8.0$ for trypsin hydrolysis. The proteases were added at the ratio of $1 \mathrm{~g}$ of enzyme to $10 \mathrm{~g}$ of protein. Hydrolysis was carried out at the respective optimum temperatures of each protease, namely $60{ }^{\circ} \mathrm{C}$ for alcalase and $37^{\circ} \mathrm{C}$ for papain and trypsin. Hydrolysates were collected at $0 \mathrm{~h}$ and after $3 \mathrm{~h}$ of hydrolysis. The 0 - $\mathrm{h}$ hydrolysate was taken as treatment control; it was collected immediately after the addition of a protease to the protein isolate-containing phosphate buffer. The 0- and 3-h hydrolysate samples collected were immediately heated in boiling water for 15 min to inactivate the proteases. The hydrolysates were then freeze-dried and stored at $-20^{\circ} \mathrm{C}$ until used.

\section{Preparation of peptide fractions by membrane ultrafiltration}

The 3-h alcalase hydrolysate was fractionated by size through a two-step centrifugal ultrafiltration process using membranes having molecular weight cut-off (MWCO) of 3 and $10 \mathrm{kDa}$. The $<3$ $\mathrm{kDa}, 3$ - $10 \mathrm{kDa}$ and > $10 \mathrm{kDa}$ fractions obtained were freeze-dried and stored at $-20{ }^{\circ} \mathrm{C}$ until used.

\section{Determination of peptide contents}

Peptide contents of hydrolysates and membrane ultrafiltration fractions were determined by using o-phthaldialdehyde (OPA) reagent [1]. Casein peptone was used to generate a standard curve for the assay.

\section{Determination of metal chelating and radical scavenging activity}

Iron chelating activity of hydrolysates and ultrafiltration fractions was evaluated as outlined in [6]. Copper chelating activity was determined as described in [7], with minor modifications. EDTA disodium was used as positive control in both assays. 2, 2'-azino-bis(3-ethylbenzothiazoline-6-sulphonic acid) (ABTS) radical scavenging activity was determined as described in [8]. Hydroxyl radical scavenging activity was assessed for as outlined in [9], with minor modifications. Reduced glutathione, a naturally occurring tripeptide antioxidant [10] was used as positive control in ABTS radical and hydroxyl radical scavenging assays.

\section{Protective effect against oxidative protein damage}

The ability of the stingray hydrolysates and ultrafiltration fractions to protect bovine serum albumin (BSA) from in vitro oxidative damage was assessed as outlined in [11]. Visualisation of BSA integrity following exposure to Fenton reagent was carried out by using a sodium dodecyl sulphate-polyacrylamide gel [12]. To determine the relative amount of BSA represented by each band, intensities of the 
bands were quantified using the ImageJ software (version 1.46, National Institutes of Health, Bethesda, MD, USA). The density of each band was standardised relative to the control band.

\section{Data analysis}

Experiments were carried out in triplicates. Data presented are mean \pm standard error of the mean (SEM). Statistical analyses were performed using Statistical Analysis System software (version 9.2). Data were analysed by one-way ANOVA test and means of significant differences were separated using Fisher's least significant difference (LSD) test or Student's ttest at $\alpha=0.05$. $E C_{50}$, defined as the sample concentration required to achieve $50 \%$ activity, was determined by using linear regression analysis.

\section{RESULTS}

Alcalase, papain and trypsin were successfully used to produce hydrolysates having enhanced peptide contents from blue-spotted stingray protein isolates (Table 1). After $3 \mathrm{~h}$ of protease treatments, the resulting $3 \mathrm{~h}$ alcalase, papain, and trypsin hydrolysates $(3 \mathrm{AH}, 3 \mathrm{PH}$, and $3 \mathrm{TH})$ had 2.6-, 2.8-, and 2.2-fold increases respectively in peptide contents compared with their respective 0 -hour hydrolysates $(0 \mathrm{AH}, 0 \mathrm{PH}$, and $0 \mathrm{TH}$ ). Notably, among the $3 \mathrm{~h}$ hydrolysates, $3 \mathrm{AH}$ had the highest peptide content, which was about 2-fold higher compared to $3 \mathrm{PH}$ and $3 \mathrm{TH}$.

For iron chelating activity, the $\mathrm{EC}_{50}$ of $3 \mathrm{AH}$ decreased by $35 \%$ compared with $\mathrm{OAH}$ (Table 1). In contrast, $3 \mathrm{TH}$ had a higher $\mathrm{EC}_{50}$ value relative to $0 \mathrm{TH}$, whereas $\mathrm{OPH}$ and $3 \mathrm{PH}$ had similar $\mathrm{EC}_{50}$ values. For iron chelating activity, the $\mathrm{EC}_{50}$ of $3 \mathrm{AH}$ was 3.4-fold higher than that of EDTA disodium. For copper chelating activity, 3 $\mathrm{h}$ hydrolysates generally had lower $\mathrm{EC}_{50}$ values compared with $0 \mathrm{~h}$ hydrolysates. $3 \mathrm{AH}$ had the lowest $\mathrm{EC}_{50}$ value among all hydrolysates, which was 2.6-fold and 2.9-fold lower compared with $3 \mathrm{PH}$ and $3 \mathrm{TH}$. $\mathrm{EC}_{50}$ of $3 \mathrm{AH}$ was 18-fold higher than that of EDTA disodium. Similar to copper chelating activity, the ABTS radical scavenging activity of $3 \mathrm{AH}, 3 \mathrm{PH}$ and $3 \mathrm{TH}$ was enhanced, as indicated by their lower $\mathrm{EC}_{50}$ values compared with $\mathrm{OAH}, \mathrm{OPH}$ and $0 \mathrm{TH}$. For $\mathrm{ABTS}$ radical scavenging activities, the $\mathrm{EC}_{50}$ of $3 \mathrm{AH}$ was the lowest among all hydrolysates, although it was 16-fold higher compared with reduced glutathione. Based on $\mathrm{EC}_{50}$ values, $3 \mathrm{AH}$ exhibited the strongest iron chelating, copper chelating and ABTS radical scavenging activities among all three protein hydrolysates analysed.

Three membrane ultrafiltration fractions were obtained: < $3 \mathrm{kDa}, 3$ - $10 \mathrm{kDa}$, and > $10 \mathrm{kDa}$ fractions. The 3 - $10 \mathrm{kDa}$ fraction had the highest peptide content, whereas the $>10 \mathrm{kDa}$ fraction had the lowest (Table 2). Among the three ultrafiltration fractions, the $<3 \mathrm{kDa}$ fraction had the highest iron chelating activity (Table 2). The $\mathrm{EC}_{50}$ of $<3 \mathrm{kDa}$ fraction was $53 \%$ and $45 \%$ lower than those of $3-10 \mathrm{kDa}$ and > $10 \mathrm{kDA}$ fractions, respectively.

When compared to $3 \mathrm{AH}$ (Table 1) and EDTA disodium, the $\mathrm{EC}_{50}$ of the $<3 \mathrm{kDa}$ fraction was 2.6-fold and 8.8-fold higher, respectively. For copper chelating activity, > $10 \mathrm{kDa}$ fraction had the lowest $\mathrm{EC}_{50}$ value among the three fractions; the $\mathrm{EC}_{50}$ value was also $31 \%$ lower compared with $3 \mathrm{AH}$. When compared with EDTA disodium, the $\mathrm{EC}_{50}$ of $>10 \mathrm{kDa}$ fraction was 12-fold higher.

Table 1: Peptide contents and antioxidant activities of protein hydrolysates

\begin{tabular}{|c|c|c|c|c|}
\hline \multirow[b]{2}{*}{ Hydrolysate } & \multirow{2}{*}{$\begin{array}{l}\text { Peptide content } \\
\text { ( } \mathrm{mg} / \mathrm{g} \text { of freeze- } \\
\text { dried hydrolysate) }\end{array}$} & \multicolumn{3}{|l|}{$E C_{50}(\mu \mathrm{g} / \mathrm{mL})$} \\
\hline & & $\begin{array}{l}\text { Iron chelating } \\
\text { activity }\end{array}$ & $\begin{array}{l}\text { Copper chelating } \\
\text { activity }\end{array}$ & $\begin{array}{l}\text { ABTS radical } \\
\text { scavenging activity }\end{array}$ \\
\hline $\mathrm{OAH}$ & $169.1 \pm 3.0^{a}$ & $177.8 \pm 0.4^{*}$ & $6131.0 \pm 160.2^{*}$ & $1437.3 \pm 47.7^{*}$ \\
\hline $3 \mathrm{AH}$ & $433.9 \pm 3.9^{\mathrm{b}}$ & $116.4 \pm 0.8^{*}$ & $2136.9 \pm 13.9^{*}$ & $793.9 \pm 16.6^{*}$ \\
\hline $\mathrm{OPH}$ & $77.5 \pm 1.9^{c}$ & $211.9 \pm 3.8^{*}$ & $44944.8 \pm 14437.5^{*}$ & $2115.9 \pm 15.9^{*}$ \\
\hline $3 \mathrm{PH}$ & $213.5 \pm 4.0^{\mathrm{d}}$ & $212.2 \pm 2.1^{*}$ & $5515.4 \pm 235.6^{*}$ & $1132.6 \pm 16.9^{*}$ \\
\hline OTH & $94.1 \pm 1.0^{\mathrm{e}}$ & $137.8 \pm 6.8^{*}$ & ND & $2381.3 \pm 19.6^{*}$ \\
\hline 3TH & $203.7 \pm 0.6^{\dagger}$ & $162.6 \pm 7.6^{*}$ & $6281.4 \pm 616.1^{*}$ & $1335.9 \pm 11.3^{*}$ \\
\hline Positive control & - & $33.9 \pm 0.9$ & $121.3 \pm 0.2$ & $51.2 \pm 0.5$ \\
\hline
\end{tabular}

Data are presented as mean \pm SEM ( $n=3)$. $E C_{50}$ denotes the sample concentration required to achieve $50 \%$ activity. $O A H=O \mathrm{~h}$ alcalase hydrolysate; $3 A H=3 h$ Alcalase hydrolysate; $O P H=0$ h Papain hydrolysate; $3 P H=3$ h Papain hydrolysate; $0 T H=0$ h trypsin hydrolysate; $3 T H=3 h$ Trypsin hydrolysate. ND, activity undetectable. For peptide content data, values followed by different superscripts (a-f) are significantly different $(p<0.05)$ as determined by Fisher's $L S D$ test. For $E C_{50}$ data, asterisks ( $\left.{ }^{*}\right)$ indicate mean values that are significantly different $(p<0.05)$ from that of the positive control, as determined by Student's t-test 
For ABTS radical scavenging activity, the 3 - 10 $\mathrm{kDa}$ fraction had the lowest $\mathrm{EC}_{50}$ value, followed by $<3 \mathrm{kDa}$ and then $>10 \mathrm{kDa}$ fraction. When compared with reduced glutathione, the $\mathrm{EC}_{50}$ of $>10 \mathrm{kDa}$ fraction was 9.7-fold higher. The $\mathrm{EC}_{50}$ for the $3-10 \mathrm{kDa}$ fraction was $37 \%$ lower than that of $3 \mathrm{AH}$. Based on $\mathrm{EC}_{50}$ values, the $<3 \mathrm{kDa}$ fraction had the strongest iron chelating activity; the $>10 \mathrm{kDa}$ fraction had the strongest copper chelating activity; and the $3-10 \mathrm{kDa}$ fraction had the strongest $A B T S$ radical scavenging activity.

To find out if the $3 \mathrm{~h}$ hydrolysates and membrane ultrafiltration fractions also possessed scavenging activity against biologically-relevant free radicals, we have tested them for hydroxyl radical scavenging activity. All $3 \mathrm{~h}$ hydrolysates exhibited concentration-dependent increase in hydroxyl radical scavenging activity within the concentration range tested $(\mathrm{Fig} 1 \mathrm{~A}) .3 \mathrm{AH}\left(\mathrm{EC}_{50}=\right.$ $6.93 \mathrm{mg} / \mathrm{mL}$ ) showed higher hydroxyl radical scavenging activity than $3 \mathrm{PH}\left(\mathrm{EC}_{50}=9.59\right.$ $\mathrm{mg} / \mathrm{mL})$ and $3 \mathrm{TH}\left(\mathrm{EC}_{50}=9.34 \mathrm{mg} / \mathrm{mL}\right)$. For the ultrafiltration fractions prepared from $3 \mathrm{AH}$ (Fig 1B), we found the $<3 \mathrm{kDa}$ and $3-10 \mathrm{kDa}$ fractions to have similar hydroxyl radical scavenging activities, both being higher compared with the $>10 \mathrm{kDa}$ fraction. The $\mathrm{EC}_{50}$ values of the three fractions were 4.01, 3.94 and $11.38 \mathrm{mg} / \mathrm{mL}$, respectively. The $\mathrm{EC}_{50}$ values of < $3 \mathrm{kDa}$ and 3 - $10 \mathrm{kDa}$ fractions were not statistically different $(p>0.05)$ from that of reduced glutathione $\left(E C_{50}=4.11 \mathrm{mg} / \mathrm{mL}\right)$, as determine by student's t-test.
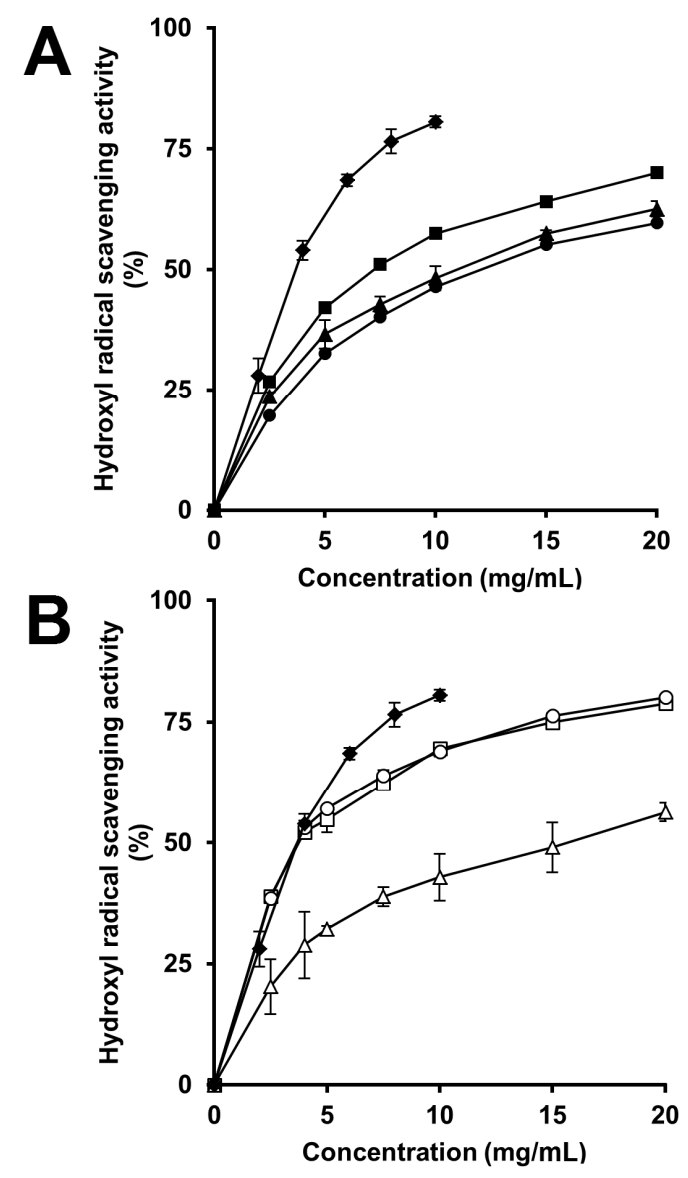

Fig 1: Hydroxyl radical scavenging activity of (A) $3 \mathrm{~h}$ hydrolysates (3AH $(\boldsymbol{\bullet}), 3 \mathrm{PH}(\bullet)$, and $3 \mathrm{TH}(\boldsymbol{\Delta}))$ and $(\mathrm{B})$ ultrafiltration fractions (<3 kDa ( $\square$ ), 3-10 kDa (o), >10 $\mathrm{kDa}(\Delta))$. Reduced glutathione $(\diamond)$. Data points are mean $\pm \operatorname{SEM}(n=3)$

Table 2: Peptide contents and antioxidant activity of membrane ultrafiltration fractions obtained from $3 \mathrm{AH}$

\begin{tabular}{lllll}
\hline \multirow{2}{*}{ Fraction } & $\begin{array}{l}\text { Peptide content } \\
\text { (mg/g of freeze- } \\
\text { dried fraction) }\end{array}$ & $\begin{array}{l}\mathrm{EC}_{50}(\boldsymbol{\mu g} / \mathrm{mL}) \\
\text { Iron chelating } \\
\text { activity }\end{array}$ & $\begin{array}{l}\text { Copper chelating } \\
\text { activity }\end{array}$ & $\begin{array}{l}\text { ABTS radical } \\
\text { scavenging activity }\end{array}$ \\
\hline$<3 \mathrm{kDa}$ & $470.2 \pm 3.9^{\mathrm{a}}$ & $297.6 \pm 4.9^{*}$ & $1800.9 \pm 14.1^{*}$ & $611.1 \pm 20.5^{*}$ \\
$3-10 \mathrm{kDa}$ & $553.4 \pm 2.3^{\mathrm{b}}$ & $632.2 \pm 10.3^{*}$ & $1841.1 \pm 12.1^{*}$ & $496.5 \pm 6.1^{*}$ \\
$>10 \mathrm{kDa}$ & $227.1 \pm 4.3^{\mathrm{c}}$ & $540.8 \pm 8.7^{*}$ & $1480.9 \pm 13.9^{*}$ & $802.8 \pm 20.9^{*}$ \\
Positive control & - & $33.9 \pm 0.9$ & $121.3 \pm 0.2$ & $51.2 \pm 0.5$ \\
& & (EDTA disodium) & (EDTA disodium) & (Reduced glutathione) \\
\hline
\end{tabular}

Data are presented as mean \pm SEM $(n=3)$. For peptide content data, values followed by different superscripts $(a-c)$ are significantly different $(p<0.05)$ as determined by Fisher's $L S D$ test. For $E C_{50}$ data, asterisks (*) indicate mean values that are significantly different $(p<0.05)$ from that of the positive control, as determined by Student's t-test

When BSA was treated with the Fenton's reagent without any added hydrolysates or fractions, the remaining amount of BSA detected was negligible (Fig 2A, lane 2). However, supplementation of hydrolysates and ultrafiltration fractions significantly increased the amount of BSA that remained after exposure to Fenton's reagent (Fig 2B). 3AH supplementation at $20 \mathrm{mg} / \mathrm{mL}$ resulted in higher BSA band intensity $(56.4 \%)$ compared with $3 \mathrm{PH}(47.1 \%)$ and $3 \mathrm{TH}(40.8 \%)$. When the three ultrafiltration fractions were compared, addition of $<3 \mathrm{kDa}$ fraction to BSA resulted in the highest band intensity (56.3 \%). Notably, addition of $3 \mathrm{AH}$ and $<3 \mathrm{kDa}$ fraction to BSA both resulted in band 


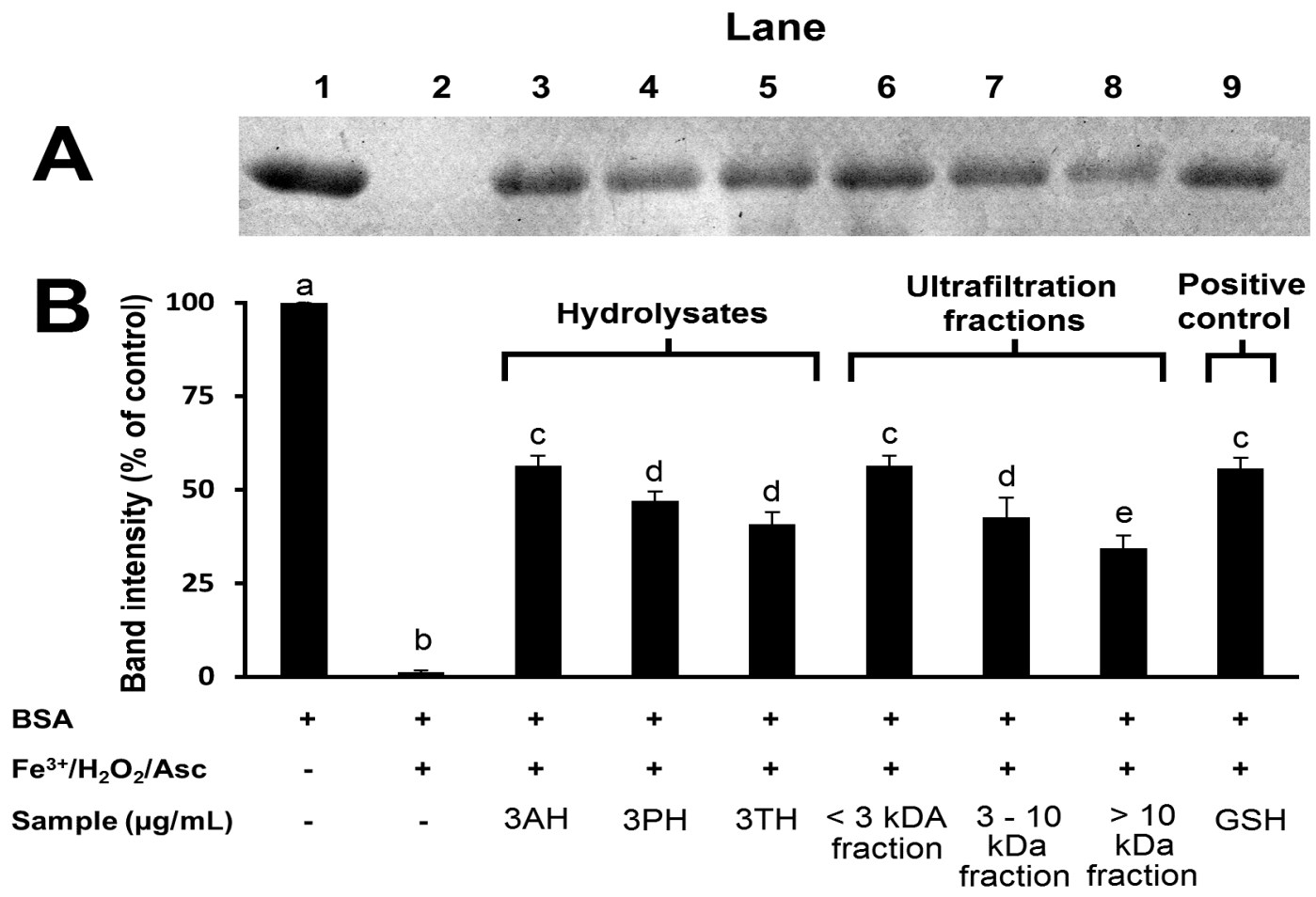

Fig 2: A typical gel image of BSA treated with Fenton's reagent $\left(\mathrm{Fe}^{3+} / \mathrm{H}_{2} \mathrm{O}_{2} /\right.$ ascorbic acid) in the presence and absence of hydrolysates and ultrafiltration fractions $(A)$ as well as densitometric analysis of the corresponding BSA bands $(B)$. Each bar represents mean $\pm \operatorname{SEM}(n=3)$. Mean values denoted by different superscript letters are significantly different $(p<0.05)$ as determined by Fisher's LSD test. GSH, reduced glutathione

intensities comparable to that of BSA supplemented with reduced glutathione.

\section{DISCUSSION}

Different proteinaceous raw materials, when hydrolysed, are known to yield hydrolysates with different bioactive and nutritional values [2]. The antioxidant properties of protein hydrolysates derived from numerous bony marine fishes have been reported [2,3]. However, studies on the antioxidant potential of protein hydrolysates prepared from edible, cartilaginous marine fishes are uncommon. In this study, we demonstrated for the first time the antioxidant capacity of protein hydrolysates and membrane ultrafiltration fractions prepared from the blue-spotted stingray. Among the three proteases used, alcalase hydrolysis stood out as the best for the production of protein hydrolysate exhibiting antioxidant activity. Hydrolysis with alcalase, unlike that with papain and trypsin, consistently enhanced the iron chelating, copper chelating and $A B T S$ radical scavenging activities of the resultant 3-h hydrolysate. $3 \mathrm{AH}$ also exhibited the strongest metal chelating and ABTS radical scavenging activities among the 3-h hydrolysates. Our results concur with previous observations of the ability of alcalase hydrolysates of fish proteins to chelate pro- oxidant metal ions and scavenge free radicals [3]. Furthermore, among the three protease treatments, hydrolysis with alcalase led to the highest peptide content in the $3 \mathrm{~h}$ hydrolysate. This finding agrees with the proposition that alcalase and other microbial proteases are relatively effective in the production of $\mathrm{FPH}$, which explains their wider uses compared with plant proteases (e.g. papain) and animal proteases (eg. trypsin) in hydrolysate production [2].

Considering that $3 \mathrm{AH}$ had the most promising metal chelating and $A B T S$ radical scavenging activities, we fractionated $3 \mathrm{AH}$ to yield three peptidic fractions by using the membrane ultrafiltration technique. The $3-10 \mathrm{kDa}$ fraction had the highest peptide content, implying that a large proportion of the peptides in $3 \mathrm{AH}$ were likely between $3 \mathrm{kDa}$ and $10 \mathrm{kDa}$ in molecular size. All three fractions, however, showed lower iron chelating activity than $3 \mathrm{AH}$. This suggests that the iron chelating activity detected in $3 \mathrm{AH}$ may have resulted from additive or synergistic actions of the three peptide fractions. On the other hand, the copper chelating activity of all three ultrafiltration fractions surpassed that of $3 \mathrm{AH}$. This suggests that the three peptide fractions may have exerted antagonistic effects among themselves in $3 \mathrm{AH}$. Both $<3 \mathrm{kDa}$ and 3 - 
$10 \mathrm{kDa}$ fractions showed higher ABTS radical scavenging activity than $3 \mathrm{AH}$, with $3-10 \mathrm{kDa}$ fraction being the stronger of the two. Hence, the $3-10 \mathrm{kDa}$ fraction was possibly a key contributor to the ABTS radical scavenging activity detected in $3 \mathrm{AH}$. In general, the lowest molecular weight hydrolysate fraction (< $3 \mathrm{kDA})$ was associated with the highest iron chelating but not with the highest copper chelating and ABTS radical scavenging activities. This is similar to the findings on the ultrafiltration fractions of silver carp hydrolysate prepared with alcalase treatment [13]. The study found that the lowest molecular weight hydrolysate fraction may or may not have the highest antioxidant activity, depending on the type of antioxidant parameters tested.

We have used the ABTS radical scavenging assay to compare the antioxidant activities of the protein hydrolysates and ultrafiltration fractions. The assay is widely used for antioxidant screening owing to its rapid and simple nature. ABTS, nevertheless, are not biological-relevant free radicals. Thus, we further characterised the antioxidant potential of the $3 \mathrm{~h}$ hydrolysates and ultrafiltration fractions by evaluating their hydroxyl radical scavenging activity and their protective effects against oxidative protein damage. Hydroxyl radicals are the most reactive of all ROS, capable of reacting with and damaging most biomolecules in living cells [14]. Proteins are the major targets of ROS in cells not only due to their high abundance as well as their active participation in most cellular processes. Oxidative protein damage is associated with aging and human pathologies [15].

The $<3 \mathrm{kDa}$ fraction was as potent as reduced glutathione in quenching hydroxyl radicals and in protecting against oxidative protein damage. The results suggest that peptides of less than $3 \mathrm{kDa}$ in size may be the primary contributor to the hydroxyl radical scavenging and proteinprotective effects observed in $3 \mathrm{AH}$. Notably, the findings on the potency of the $<3 \mathrm{kDa}$ fraction also support previous observations that the antioxidant effects of FPH are often attributed to peptides of less than $3 \mathrm{kDa}$ in length $[2,3]$. Furthermore, antioxidant potential of FPH is also influenced by their amino acid composition and sequence [2]. Thus future research is warranted to investigate the two parameters in the $<3 \mathrm{kDa}$ fraction to better understand the molecular basis for its promising antioxidant activity.

\section{CONCLUSION}

Alcalase is more effective than papain and trypsin when used to produce antioxidative protein hydrolysate from blue-spotted stingray. Hydrolysis with alcalase enhances the peptide content as well as metal chelating and ABTS radical scavenging activities of the hydrolysate. Importantly, the $<3 \mathrm{kDa}$ peptide fraction is as potent as reduced glutathione in scavenging hydroxyl radicals and in protecting proteins from oxidative damage. Our results suggest that alcalase hydrolysate and specifically its $<3 \mathrm{kDa}$ fraction have promising potential for future applications in antioxidant therapy and health food formulation.

\section{ACKNOWLEDGEMENT}

This research was supported by Fundamental Research Grant Scheme (FRGS) of Ministry of Education, Malaysia.

\section{REFERENCES}

1. Bah CSF, Bekhit AE-DA, Carne A, McConnell MA. Production of bioactive peptide hydrolysates from deer, sheep and pig plasma using plant and fungal protease preparations. Food Chem 2015; 176: 54-63.

2. Benjakul S, Yarnpakdee S, Senphan T, Halldorsdottir SM, Kristinsson HG (2014) Fish Protein Hydrolysates: Production, Bioactivities, and Applications. Antioxidants and Functional Components in Aquatic Foods, ed Kristinsson HG (John Wiley \& Sons, Ltd, Chichester, UK), pp 237281.

3. Chalamaiah $M$, Dinesh kumar $B$, Hemalatha $R$, Jyothirmayi T. Fish protein hydrolysates: Proximate composition, amino acid composition, antioxidant activities and applications: $A$ review. Food Chem 2012; 135(4): 3020-3038.

4. Marmon SK, Undeland I. Effect of alkaline $\mathrm{pH}$-shift processing on in vitro gastrointestinal digestion of herring (Clupea harengus) fillets. Food Chem 2013; 138(1): 214-219.

5. Bradford MM. A rapid and sensitive method for the quantitation of microgram quantities of protein utilizing the principle of protein dye binding. Anal Biochem 1976; 72: 248-254.

6. Chai T-T, Panirchellvum E, Ong H-C, Wong F-C. Phenolic contents and antioxidant properties of Stenochlaena palustris, an edible medicinal fern. Bot Stud 2012; 53(4): 439-446.

7. Torres-Fuentes C, Alaiz M, Vioque J. Affinity purification and characterisation of chelating peptides from chickpea protein hydrolysates. Food Chem 2011; 129(2): 485-490.

8. Wong F-C, Chai T-T, Hoo Y-W. Antioxidation and cytotoxic activities of selected medicinal herbs used in Malaysia. J Med Plants Res 2012; 6(16): 31693175. 
9. Zhu K, Zhou H, Qian H. Antioxidant and free radicalscavenging activities of wheat germ protein hydrolysates (WGPH) prepared with alcalase. Process Biochem 2006; 41(6): 1296-1302.

10. Alashi AM, Blanchard CL, Mailer RJ, Agboola SO, Mawson AJ, He R, Girgih A, Aluko RE. Antioxidant properties of Australian canola meal protein hydrolysates. Food Chem 2014; 146: 500-506.

11. Kızıl G, Kızıl M, Çeken B, Yavuz M, Demir H. Protective Ability of Ethanol Extracts of Hypericum Scabrum $L$. and Hypericum Retusum Aucher Against the Protein Oxidation and DNA Damage. Int J Food Prop 2011; 14(4): 926-940.
12. Chua N-H. Electrophoretic analysis of chloroplast proteins. Methods Enzymol 1980; 69: 434-446.

13. Dong S-Y, Zhao $Y-H$, Xu D-X, Liu Z-Y, Zeng $M-Y$. Assessing the antioxidant activity of the ultrafiltration fractions from silver carp protein hydrolysate by different antioxidant methods. J Aquat Food Prod Technol 2013; 22(6): 573-583.

14. Castro L, Freeman BA. Reactive oxygen species in human health and disease. Nutrition 2001; 17(2): 161-165.

15. Dalle-Donne I, Rossi R, Colombo R, Giustarini D, Milzani A. Biomarkers of oxidative damage in human disease. Clin Chem 2006; 52(4): 601-623. 